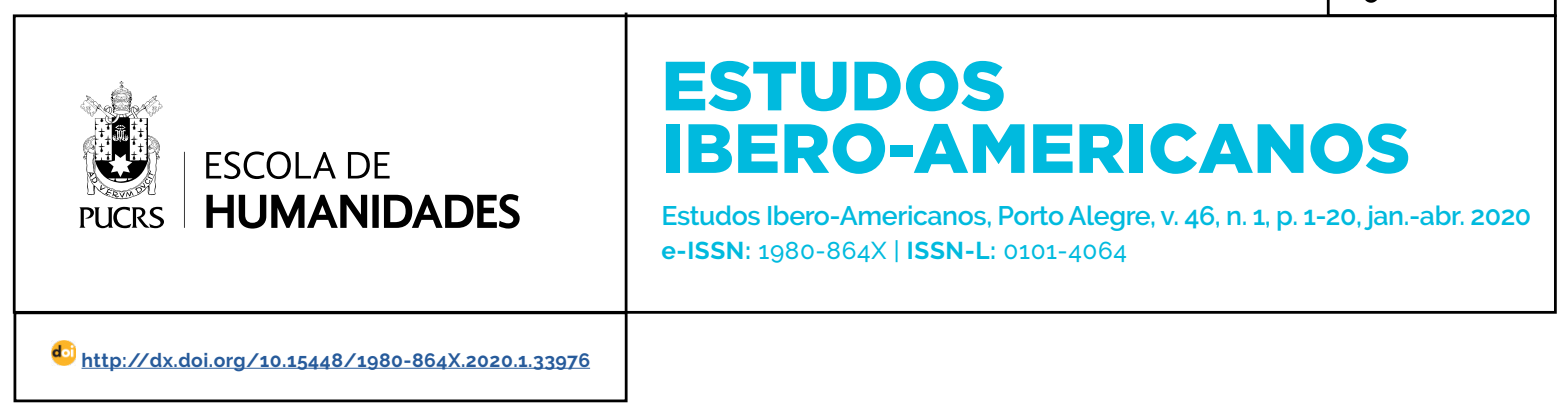

DOSSIÊ

\title{
Leucaena leucocephala (Lam.) de Wit in Brazil: history of an invasive plant.
}

\author{
Leucaena leucocephala (Lam.) de Wit no Brasil: história de uma planta invasora. \\ Leucaena leucocephala (Lam.) de Wit en Brasil: historia de una planta invasora.
}

\section{Marilia Teresinha de \\ Sousa Machado ${ }^{1}$}

orcid.org/0000-0002-3187-6553

mariliatsm@yahoo.com.br

\section{José Augusto \\ Drummond $^{1}$}

orcid.org/0000-0002-7349-0579

jaldrummond@uol.com.br

\section{Cristiane Gomes \\ Barreto ${ }^{1}$}

orcid.org/0000-0003-3509-3158

crisbarreto@unb.br

Recebido em: 07 mai. 2019.

Aceito em: 11 set. 2019.

Publicado em: 22 abr. 2020.
ABSTRACT: The purpose of this text is to provide a long-term record of occurrences of the species Leucaena leucocephala (Lam.) de Wit. in the Brazilian territory, in order to (i) determine if its introduction occurred before the earliest official record, (ii) identify points of occurrence in Brazil, and (iii) assess its status as a useful although invasive plant. The text is partly based on research done on the confirmed presence of this plant in the Brasilia National Park, located in Brazil's Federal District. Three databases available on the Internet containing information from several herbariums were accessed to obtain the location and the dates of the relevant records of the plant in Brazilian territory. We found that the species was rather widely present in the Brazilian territory before the official record of its earliest introduction. In addition, we found that the plant's current geographic distribution indicates that it continues to have a strong invasive potential in Brazil, especially because there are social and technical incentives to cultivate it in rural properties. Key words: Leucaena leucocephala. geographical occurrence. invasive species. Brazil.

RESUMO: O objetivo deste texto é oferecer um histórico de longo prazo das ocorrências da espécie Leucaena leucocephala (Lam.) de Wit. no território brasileiro, para (i) determinar se a sua introdução aconteceu antes da data oficial de seu primeiro registro, (ii) identificar os seus pontos de ocorrência no Brasil e (iii) avaliar o seu status como uma planta útil, mesmo que invasiva. O texto se baseia em parte em pesquisa conduzida sobre a presença confirmada dessa espécie de origem exótica no Parque Nacional de Brasília, Distrito Federal. Foram acessadas três bases de dados disponiveis na Internet para obter a localização e as datas dos registros relevantes da planta no território brasileiro. A pesquisa constatou que a espécie tinha uma presença relativamente abrangente no Brasil muito antes do primeiro registro oficial de sua introdução. Além disso, foi constatado que a atual distribuição geográfica da planta indica que ela continua a ter um forte potencial invasivo no Brasil, especialmente porque existem incentivos econômicos e técnicos para o seu cultivo em propriedades rurais.

Palavras-chave: Leucaena leucocephala. ocorrência geográfica. espécies invasivas. Brasil.

RESUMEN: El objetivo de este texto es ofrecer un histórico de largo plazo sobre la presencia de la especie Leucaena leucocephala (Lam.) de Wit. en el territorio brasileño para (i) determinar si su introducción sucedió antes de la fecha inicial de su primer registro, (ii) identificar los puntos de aparición en el Brasil y, (iii) evaluar su estatus como una planta útil, a pesar de ser invasiva. El texto se basa en parte en una investigación sobre la presencia confirmada de esta especie de origen exótica en el Parque Nacional de Brasília, en el Distrito Federal brasileño. Fueron consultadas tres bases de datos disponibles en internet para obtener la ubicación y las fechas de los registros relevantes de la planta en el territorio brasileño. La investigación constató que la especie tenía una presencia relativamente amplia en el Brasil mucho antes del primer registro oficial de su introducción. Adicionalmente, se constató que la distribución geográfica actual de la planta indica que la misma aún tiene un fuerte potencial invasivo en Brasil, especialmente porque existen incentivos económicos y técnicos para su cultivo en propiedades rurales. Palabras-claves: Leucaena leucocephala. presencia geográfica, especies invasivas. Brasil.
Artigo está licenciado sob forma de uma licença Creative Commons Atribuicão 4.0 Internacional. 


\section{Introduction}

The species Leucaena leucocephala (Lam.) de Wit. is native to the current territory of Mexico. The exact date and the circumstances of its arrival in Brazil are unknown. Vilela and Pedreira (1976) reported that the earliest introduction occurred in the state of São Paulo in November 1940, by the initiative of the Instituto Agronomico do Estado de São Paulo (Agronomic Institute of the State of São Paulo), a São Paulo state agency, under the code number I - 4.218. The institute used seeds donated by the federal Serviço Florestal do Rio de Janeiro (Rio de Janeiro Forest Service), an agency under the Ministério da Agricultura, Indústria e Comércio (Department of Agriculture, Industry and Commerce) in charge of forest policies (BEDIAGA; DRUMMOND, 2007). The origin of these seeds is not given. Until now 1940 was considered the official year of the plant's introduction in Brazil.

In this article we try to answer the following question: Are there records of the presence of the species in the Brazilian territory prior to 1940 ? We sought to answer this question in order to aid the understanding of its invasive traits and its current wide distribution throughout the Brazilian territory. We used records of the occurrence of the species present in three databases, which include the collections of 183 herbaria managed by several research institutions in Brazil and abroad. These databases are available on the Internet - speciesLink, Flora do Brasil 2020. and Global Biodiversity Information Facility (GBIF). Herbaria data were used to answer the aforementioned question. These data open new perspectives on the origin and present distribution of the species Leucaena leucocephala in Brazil.

\section{Exotic and invasive species as a topic for environmental historians.}

The study of exotic or invasive species (plants, animals and microorganisms) is a relatively recent, but challenging and controversial field for ecologists, conservationists, geneticists, public health researchers, biogeographers and environmental historians. The standard initial statement on the subject was made in the 1950 s by an ecologist, Charles Elton (ELTON, 2000 [1958]). Understanding the role of human societies in the deliberate or accidental movement of organisms beyond their natural range reveals important dimensions of the interplay between human culture and the natural environment and helps understand the myriads of consequences ("good" or "bad", desired and undesired) of these events. Our study of Leucaena seeks to make a contribution to this field, combining the precepts of botanical research and classification with the perspective of environmental history (which focuses on the interplay between human culture and nature). The Leucaena case is propitious because the "good" and desired effects of this deliberately introduced plant go hand in hand with its "bad" and undesired effects.

In the cases of deliberate introductions or transfers of exotic plants and animals, humans have been motivated by a long list of needs and values. The past tense used in the following paragraphs could be substituted appropriately by the present tense, because introductions or transfers of organisms to and between societies, regions, countries and continents continue to be common and are expected to increase rapidly on a global scale (SIMBERLOFF, 2013). We will not discuss cases of unintentional introductions and transfers, even though they too may be highly relevant for environmental history research.

Utility was the paramount value in the numerous cases of deliberate transfers of domesticated plants (for food, forage of domestic animals, construction materials, medicine etc.), many times indicating the rejection of local foodstuffs by migrants recently arrived to "new" lands. Utility also drove the transfers of domesticated animals, such as cattle, horses, sheep, goats, fowl, insects (bees, silkworms) and pets, for food, work, transportation, war and companionship. Agronomic fitness and prospects of commoditization were motivations that influenced the deliberate movement of selected domesticated plants, such as sugar cane, coffee, rubber trees, cacao and dozens of other fruit trees, soybeans, potatoes, cassava, wheat, corn, rice etc. from and to many parts of the 
world, in accordance with international and global needs and market dynamics. Aesthetic fruition of flowering, colorful, unusual or otherwise evoking plants led to their transfer as ornamentals in farms, roadsides, village and city streets, urban parks and even in pots and gardens around and inside households, allowing the remembrance of familiar landscapes of previously inhabited places. Modern attempts of biological control of organisms that act as agricultural "pests" and/or harbor diseases affecting humans and their agricultural productions have sometimes led to the establishment of populations of transferred organisms intended to control these "pests". In many cases these new organisms engaged in behaviors that created other types of problems affecting human interests and the natural environments into which they were introduced as "solutions" (CROSBY, 1973. 1986; TODD, 2001; LOW, 2001; BURDICK, 2005; JOHNSON, 2010; MORETTO, 2017).

Ranking environmental historians have dealt with intentionally transferred organisms. Alfred Crosby (CROSBY, 1973, particularly in chapters 3 and 5; see also Crosby, 1986) provided the groundbreaking account on the environmental history of the "Columbian exchange". He gave this name to the widespread "swap" of plants, animals and pathogens involving autochthonous peoples of the American continent and European arrivals, starting in the early 1500 s. From East to West Europeans, or from the "Old World" to the "New World", colonizing Portuguese, Spaniards, English, Dutch and French moved sugar cane, grape vines, wheat, rice, numerous fruit trees, coffee, salad greens and dozens of others. Many of them became widely cultivated throughout the American continent, while others failed. Europeans also introduced their domesticated animals, which became quite popular among many American peoples, an important factor for their mostly successful introductions: Horses, asses, donkeys, pigs, cattle, goats, sheep, ducks, geese, chickens and others. Most of these species did very well inside and outside colonial settlements and farms, in some cases forming wild (feral) populations. Crosby stresses that these intentional additions to the American biota helped "europeanize" the landscapes that Europeans were conquering through several other means - territorial takeovers, military force, religious intolerance and conversion to Christianity. Unintentionally introduced Old World diseases - smallpox being the most deadly - completed the job: They helped break many autochthonous societies. Crosby called domesticated plants and animals, together with pathogens, a "portmanteau biota" (CROSBY, 1986, p. 270), a squad of allies that aided Europeans to conquer many lands and peoples.

Crosby gives equal importance to movements from West to East. American cultivated plants potatoes, sweet potatoes, corn, peanuts, squashes, pumpkins papayas, avocados, tomatoes, beans and many others - crossed the Atlantic and affected agriculture, diets and nutrition standards in colonizing Europeans nations, arguably aiding the strong population growth of early modern Europe. Potatoes in particular made a strong entry in areas later to become Spain, France, Germany, England, Ireland etc., where they became cheap and nutritious food for the populace, to the point of having a ominous famine named after them - the "Irish potato famine". More than a quarter of the Irish population died or migrated when a destructive "pest" attacked potatoes in the mid1840s (READER, 2008). Maize was introduced in many points of the African continent and became a highly successful crop and a staple among many different peoples (McCANN, 2007 [2005]). Crosby adds that thoroughly tropical plants like manioc became staples in tropical Africa and Asia. The New World also exported to Europe the by products of two native cultivated American plants - cotton and tobacco. Both became all important cash crops in the Americas. Their by products triumphed in Europe and beyond. Cotton fed England's textile factories and thus played a crucial role in the English industrial revolution. Tobacco soon induced a widespread addiction to cigarettes among Europeans of many countries, an addiction that later spread much further and remains a major public health issue in many countries of the world. 
In an influential methodological paper aimed at environmental history practitioners, Donald Worster (WORSTER, 1990, p. 10901091) proposed three analytical "levels" for the emerging discipline: (i) the "structure and distribution of natural environments of the past"; (ii) the "productive technology as it interacts with the [natural] environment"; and (iii) the "perceptions, ethics, laws and myths" generated by the human understanding of natural settings. Although Worster did not place special emphasis on organisms transferred from one natural environment to another, the three proposed analytical levels are neatly relevant to their study. First, these organisms will always originate in a native setting of their own, which must be properly understood by the historian in order to understand their "native" ecological traits and evaluate the new traits that they may adopt in the distinct natural setting into which they are moved. Second, many transferred organisms are central parts of agricultural technologies that interact with and change the natural settings into which they are introduced. Third, organisms that are introduced, deliberately or accidentally, are object of much human consideration, especially when they are linked to remarkable effects, either negative or positive in the eyes of the beholders. Such attention engenders folk stories, popular and scientific narratives, policies, technical appraisals, regulations etc. that the environmental historian must address. In short, besides their "practical" importance in the field, transferred organisms may well be central objects of investigation in environmental history research.

Worster opens this text with a short allusion to an episode involving a transferred organism - in this case it was an unintentional introduction ( $p$. 1087-1088). He uses this case to illustrate the call made by Aldo Leopold (Leopold, 1987 [1949], p. 205) for "an ecological interpretation of history" and to prepare his own statement in favor of an "agroecological perspective in history". The episode involves (i) the substitution of "formidable" native canebrakes by introduced bluegrass in Kentucky bottomlands in early American history and (ii) the advantages that this gave to agricultural settlers moving inland from the Atlantic coast. The dense formations of tall canebrakes were serious obstacles to the plows of newcomers. However, newcomers burned canebrakes, bluegrass formations substituted them by the natural process of "secondary ecological succession", without any additional effort by settlers. Bluegrass formations were amenable to the agriculture and the cattle of the rural pioneers. Thus it stimulated the occupation of those bottomlands by masses of pioneers who otherwise would have migrated to other places. Worster stresses that at the time of the episode and even many decades later when Leopold was writing, the origin of bluegrass was unknown. It is known now that bluegrass is a "European import", although an unintentional one. It worked as a "plant ally" in the European occupation of Kentucky, helping to displace Native American communities.

Warren Dean (DEAN, 1987) wrote an entire book on the transfer of a single plant - the seringueira or rubber tree. Native stands of seringueiras supported a fairly durable rubber latex boom in the Brazilian Amazon region from the mid- $19^{\text {th }}$ and early $20^{\text {th }}$ centuries. For several years Brazil cornered the market for latex, which was the second most valuable Brazilian export, competing with almighty coffee. Rubber was a high-priced and widely useful commodity consumed by industrialized countries to manufacture machinery, waterproof materials, bicycle and automobile tires etc. In 1875, an intentional act of smuggling seringueira seeds and seedlings to England led to the domestication of the plant and its transfer to form huge plantations in European colonies in Southeast Asia. By 1910, approximately, the output from these plantations killed the extractive boom in the Amazon. This plant transfer had widespread social and economic consequences on a global scale, involving Brazil, industrialized countries and their colonies.

A combination of several ecological factors and economic circumstances has led to Leucaena leucocephala being considered presently one of the 100 most pervasive invasive organisms of the world (LOWE et al., 2000). As a domesticated plant 
widely and intentionally dispersed throughout the world and marked by remarkable invasive characteristics (see below), Leucaena leucocephala is an exemplary case of how human motivations helped a plant escape its native range and capture footholds in many other parts of the planet. As can be said about many plants and animals upon which humans have focused their attention, needs and will, the natural history of Leucaena leucocephala was expanded into its environmental history.

\section{Methods}

\subsection{The species Leucaena leucocephala}

The genus Leucaena belongs to the family Leguminosae, subfamily Mimosoidae, and Mimosae tribe. It comprises 22 species, 4 subspecies, 2 varieties, and 2 hybrid taxa (HUGHES, 1998). They include individuals with shrub and tree sizes, varying between 5 and $18 \mathrm{~m}$ in height. They are perennial, fast growing, and adapted to tropical dry regions (BREWBAKER, 1978). They require average temperatures between $25^{\circ}$ and $30^{\circ} \mathrm{C}$ for optimal growth (HUGHES, 1998).

Before spreading around the planet, the genus was domesticated in its area of origin (EVANS, 1993), in the current territory of Mexico. It is native to the region of Chiapas and the Yucatan peninsula (DIJKMAN, 1950). Pre-Columbian civilizations spread the genus beyond its original range towards the Gulf of Mexico and the Caribbean Sea (NATIONAL ACADEMY OF SCIENCES [NAS], 1977). Brewbaker (1978) reports that the genus also occurs naturally in southern Texas (USA) and Central America. Migration of the genus to the Pacific region of Mexico occurred after the Spanish conquered Mexico and Central America.

Within the Leucaena genus, Leucaena leucocephala is the best-known species, because it is widespread and useful to humans. Morphological differences between subspecies were noticed in early agronomic evaluations. The species was classified into three major types: (i) the "Common" type is an intensely branched shrub, has slow growth, high seed production, and invasive potential; (ii) the "Giant" type has an arboreal size, can reach a height of up to $20 \mathrm{~m}$, grows vigorously and produces much wood and fodder; (iii) the "Peru" type is erect and has many branches, with a height of up to $15 \mathrm{~m}$; it produces much forage with high protein content.

The species was known until 1961 as Leucaena glauca (L.) Benth. In that year Hendrik Cornelis Dirk de Wit published a study based on a review of the botanical materials held at the Rijksherbarium, in Leyden, Netherlands, and at the Linnaeus Collection, in London, England. He found that the scientific name Mimosa glauca, given by Linnaeus, was based on Adriaan van Royen's description of 1740, and that the plant differed from Leucaena leucocephala in the characteristics of the pods and the number of stamens. De Wit concluded that the description made in 1783 by Lamarck, who named the species Mimosa leucocephala, was the first valid botanical description (HILL, 1971 apud VILELA and PEDREIRA, 1976).

The genus Leucaena was proposed in 1842 by George Bentham, who distinguished it from the genus Mimosa. In that same year, Bentham published the first description of the genus and placed it within the order Mimosae, tribe Eumimosae (ZÁRATE, 1994). The botanical name of the species accepted until now is Leucaena leucocephala (Lam.) de Wit (HILL, 1971 apud VILELA and PEDREIRA, 1976).

In its natural range, Leucaena leucocephala is used mainly as human food. Leaf buds, flowers, seeds and young pods are its most important edible components. The size, flavor and digestibility of seeds and pods are important considerations for the selection of collected and domesticated individuals. Artificial selection of course affects cultivated populations, but also wild ones. People abandon unfavorable wild specimens and help propagate those with favorable phenotypes (CASAS; CABALLERO, 1996). All varieties of Leucaena leucocephala have edible leaves and their seeds are rich in proteins. Seeds are commonly sold by street vendors and markets in northern Guatemala and southern Mexico. They can be eaten fresh or prepared in different manners (baked, broiled, sun-dried or as ingredients of pastas and sauces). Stems 
and branches may be used for construction, firewood and charcoal in Central America and parts of Mexico (HUGHES, 1993). The plant is highly valued for shading and for providing green manure in coffee, tea and rubber tree plantations in Southeast Asia. It has been widely used also in reforestation and erosion control efforts, because of its adaptability to disturbed environments. It is a good choice for stabilizing steep slopes and for restoring marginal soils and areas subject to long periods of draught (LIMA, 2005).

Nowadays the genus Leucaena is found and/or cultivated in 126 tropical and subtropical countries (GLOBAL INVASIVE SPECIES DATABASE (GISD), 2019). It plays an important set of socioeconomic roles, especially in developing countries (CATIE, 1991: WALTON, 2003; SCHIFINO-WITTMANN, 2008). Its major current use is as a component of agroforestry systems in small and medium-sized farms. (KLUTHCOUSKI, 1992). It has multiple uses in these systems, due to the high quality of its forage, its fast growth and its strong capacity for regrowth (BREWBAKER; SORENSSON, 1994). Farm animals (especially goats and sheep) easily accept it as forage (SOUSA, 2001). Despite its high content in proteins and macronutrients and its appeal to farm animals, its use as forage demands precautions, mainly because the amino acid mimosine (or leucenol) limits its use for forage. When Leucaena leucocephala surpasses 30 percent of animal intake, it may affect several metabolic functions. Thus, it should not be used as exclusive feed because it may lead to excessive production of saliva, cause the loss of fur and impair the growth of goats and sheep (SCHIFINO-WITTMANN, 2008). Nonetheless, it has gained a global status of a desirable plant in farms, ranches and city parks and streets.

In Brazil, the species has been regularly used over the last decades for economic purposes in many areas. It is cultivated especially as a forage plant (SOUSA, 2001; COSTA, N. et al., 2004). Cattle, sheep and goats (SOUSA, 2001) and wild native animals such as the paca (Cuniculus paca) appreciate its foliage (MATTOS, 2015). It may be offered to animals young or mature, green, dry or ensiled (NAS, 1977). The species is currently found, cultivated or not, in Brazil's five official geographical regions and in almost all Brazilian states, since it grows well in both the northeastern warm and semiarid region and the colder and humid southern areas (LIMA, 2005).

However, its appraisal as an important forage tree and the widespread incentives for its use in farmlands have been accompanied by a growing concern about its behavior as an exotic species. Several authors have pointed out that the plant has seven attributes typical of species with invasive potential. It (i) is fast-growing (BLOSSEY; NÖTZOLD, 1995: COSTA, J.; DURIGAN, 2010); (ii) is a heliophytic pioneer (REJMÁNEK, 1996); (iii) produces large quantities of seeds (NOBLE, 1989); (iv) can reproduce both sexually and asexually, sprouting several times after cutting; ( $v$ ) has a short prereproductive life period; (vi) displays high plasticity; and (vii) is tolerant to different environments (COSTA, J.; DURIGAN, 2010). These traits give Leucaena leucocephala strong advantages that help it outcompete many native plants, altering both natural plant formations and even some agricultural undertakings. With or without help by humans, Leucaena has spread vigorously around the world, mostly in the tropical realm. Considering these traits, scholars have identified the phases of the plant's potential invasion process, such as its introduction and possible establishment accompanied by its strong capacity for dispersal (COLAUTTI; MACISAAC, 2004).

\subsection{The use of herbarium collections}

Information for our research was gathered from several natural history collections of herbaria, museums, and botanical gardens. These collections are commonly recognized as valuable sources for researching records of the occurrence of species (PHILLIPS et al., 2004; ALBERNAZ; PIRES, 2009), particularly species new to science and species transferred from their native settings by human agency. Thus, they store relevant data for environmental historians. Herbaria provide 
two types of especially significant information for environmental historians: (i) the sites of occurrence (indicating where species are located and where they may remain) and (ii) descriptions of the compatibilities between the species and the habitat in which they were collected (MacDOUGALL et al., 1998). The same authors point out that herbarium data have limitations, but they consider that in most cases they provide reliable information for the evaluation of rare, endemic or exotic plant species.

In cases of invasive plants, herbarium data have the potential to help in the reconstruction of invasion histories (COUSENS et al., 2013) and to determine the flow of species circulation (FUENTES et al., 2008), particularly when exotics are introduced by deliberate human agency. They can also help define the limits of invaded areas over time, and to estimate the rates of spatial propagation (PYŠEK; HULME, 2005). However, there are also limitations in the use of herbaria databases, particularly for the measurement and determination of the population dispersion of potentially invasive species (HYNDMAN et al., 2015).

Despite limitations and heterogeneity in the data, herbarium records provide collection dates and geographical locations that have been useful in a number of studies. They contain valuable information about the arrival and establishment of exotic species and about the invasion process. They can also help identify points and moments in which this invasion process may undergo abrupt changes (FUENTES et al., 2008; HYNDMAN et al., 2015).

\subsection{Data sources}

Records of the occurrences of Leucaena leucocephala in Brazilian territory were extracted from three databases: speciesLink, Flora do

Brasil 2020 and GBIF. We proceeded through four steps. First, we searched records that had collection dates prior to 1940 (date of the earliest registered introduction of the species in Brazilian territory). Second, these records were compared in each database, in order to exclude possible duplicates (same location, same collector, and same year). Third, we tried to identify which records had exsicatae images with collection dates. Fourth, we classified the data set considering all collection points recorded in Brazil. Records were divided into two groups: one containing records that are geo-referenced, the other containing non geo-referenced records. The second set was considered only to tally the total number of records in the Brazilian territory. The first group was used to build maps; the second group was used to generate graphs that allow the visualization of records by decade of collection.

\section{Results}

\subsection{Records of Leucaena occurrence in Brazil prior to 1940}

Regarding the earliest official date of introduction of the species in Brazil - 1940, we found 30 records with earlier dates: 1831 (two records), 1842, 1844 , 1851, 1865 (two), 1872, 1873, 1878, 1894, 1898, 1907 (two), 1917, 1918, 1923 (two), 1927, 1932, 1934, 1935. 1936 (two), 1937, 1938 (two) e 1939 (three). The two samples from 1831, found in the state of Bahia, were the first to be collected, pushing back the introduction year from 1940 to 1831 - 109 years. This finding is a robust refutation of the official date of introduction. These 30 early records contain 20 exsicatae images, shown below.

Most of these early records were made in areas that belong to the Atlantic Forest biome. This trend continued for more recent collection and identification dates. Images 1 to 20 show the exsicatae contained in these early records. They are followed by brief comments about collectors and taxonomic classification. 


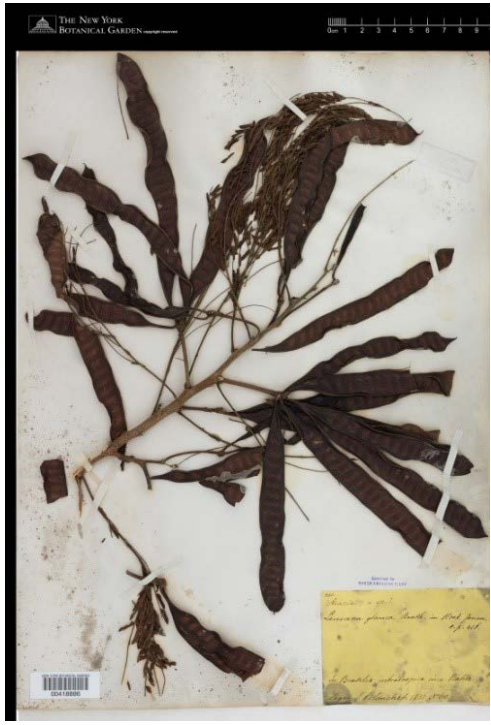

Image 1 - Exsicatae referring to 1831.

Source: The C. V. Starr Virtual Herbarium - The New York Botanical Garden, 2016.

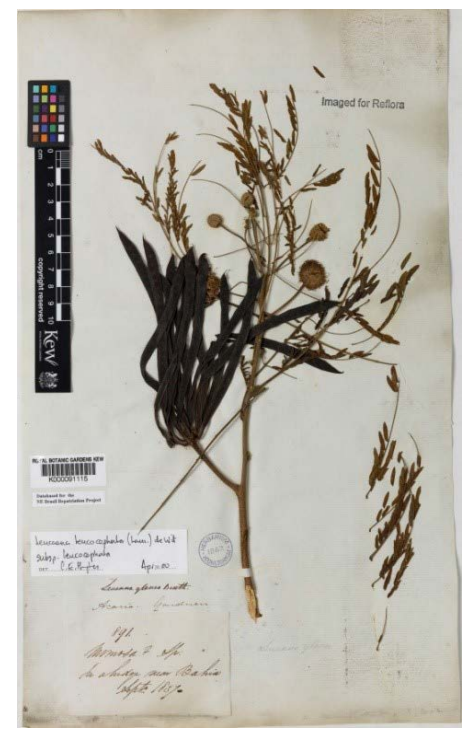

Image 2 - Exsicatae referring to 1831.

Source: Collection of Herbário Virtual Reflora, Royal Botanic Gardens, Kew, 2016.

Image 1 refers to the specimen collected in 1831 in Bahia by Jacques Samuel Blanchet (1807-1875), classified as Leucaena glauca Benth. Blanchet was a Swiss businessman and amateur naturalist who served also as Swiss consul in Bahia. He was a profitable collector between the years of 1828 and 1856. (JSTOR GLOBAL PLANTS, 2017; HARVARD UNIVERSITY HERBARIA \& LIBRARIES, 2017). Image 2 shows another specimen collected in Bahia, also in 1831, by George Gardner (1812-
1849), a British physician and botanist, who made a long research trip through the states of Bahia, Pernambuco, Ceará, Piaui, Goiás and Minas Gerais (HARVARD UNIVERSITY HERBARIA \& LIBRARIES, 2017; GARDNER; PINHEIRO, 1942). The specimen was classified as Leucaena glauca Benth, but was reclassified in April 2000 as Leucaena leucocephala (Lam.) de Wit.

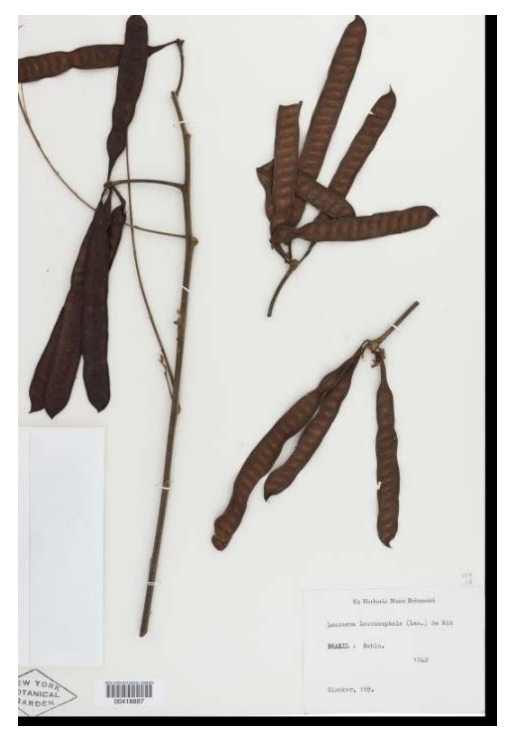

Image 3 - Exsicatae referring to 1842.

Source: The C. V. Starr Virtual Herbarium - The New York Botanical Garden, 2016.

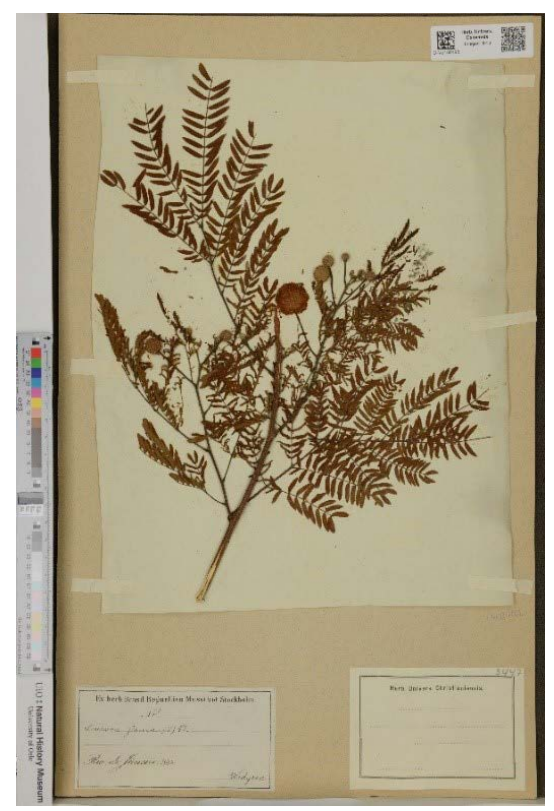

Image 4 - Exsicatae referring to 1844.

Source: Vascular Plant Herbarium - Natural History Museum, University of Oslo, 2016. 
Image 3 shows a specimen collected in 1842 by Constantine Ernest Friedrich von Glocker (17931858), a German geologist and paleontologist (HARVARD UNIVERSITY HERBARIA \& LIBRARIES, 2017). It was also collected in Bahia and classified as Leucaena leucocephala. Image 4 shows a specimen collected in 1844 by Johan Fredrik Widgren (18101883), Swedish priest and botanist (JSTOR GLOBAL PLANTS, 2017). It was collected in Rio de Janeiro and classified as Leucaena glauca Benth.

The record found for the year 1851 represents a sample collected by N. J. Anderson in Rio de Janeiro. The species was determined as Leucaena leucocephala.

Images 5 and 6 present two samples collected in 1865 by William John Burchell (1781-1863), a British botanist and draftsman. He crossed Rio de Janeiro, São Paulo, Goiás e Pará states in a long research trip (ROYAL BOTANICAL GARDEN, KEW, 2019). The species of these two samples was determined as Leucaena glauca Benth. It was reclassified as Leucaena leucocephala (Lam.) de Wit. in 2000.

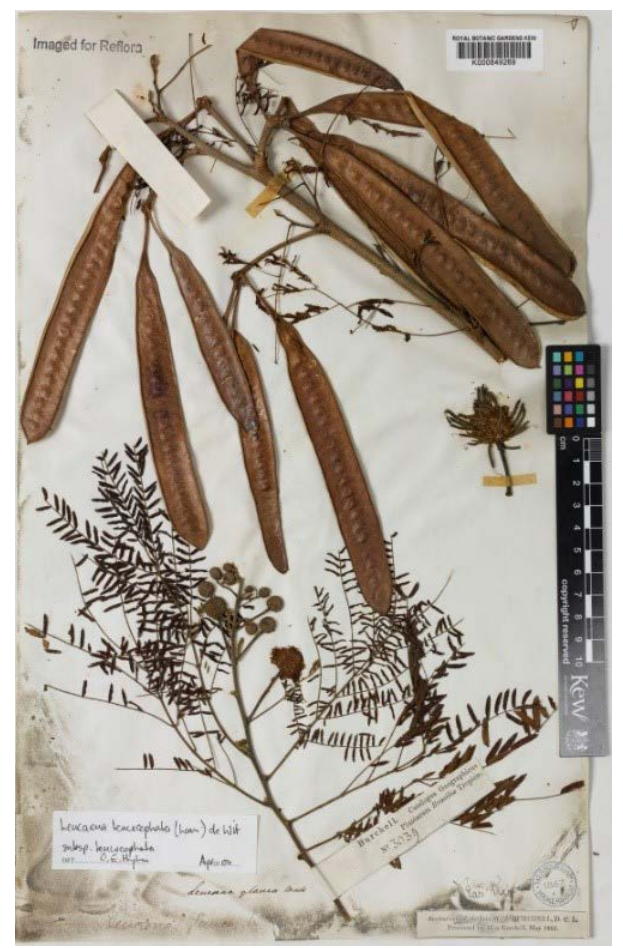

Image $\mathbf{5}$ - Exsicatae referring to 1865.

Source: Collection of Herbário Virtual Reflora, Royal Botanic Gardens, Kew, 2016.

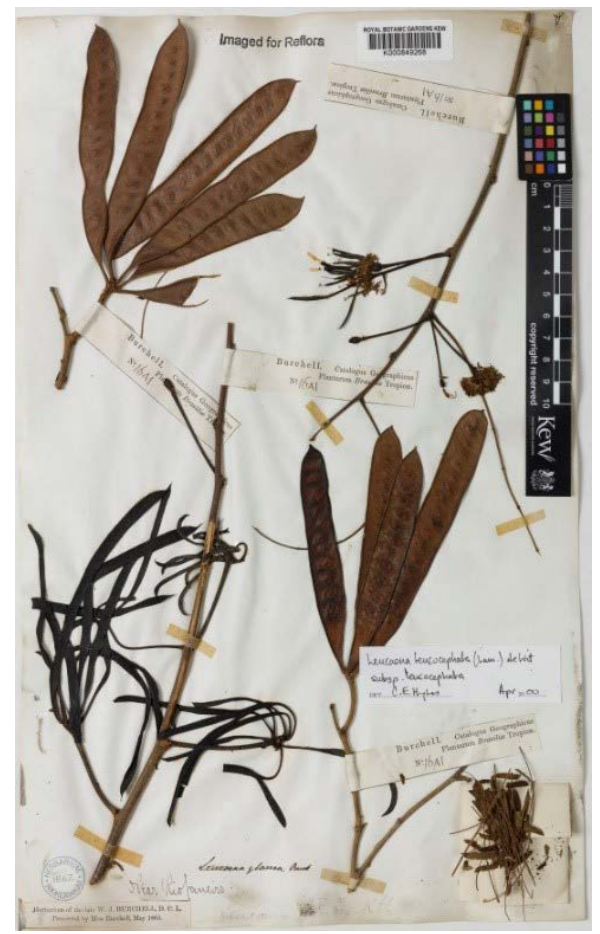

Image 6 - Exsicatae referring to 1865.

Source: Collection of Herbário Virtual Reflora, Royal Botanic Gardens, Kew, 2016.

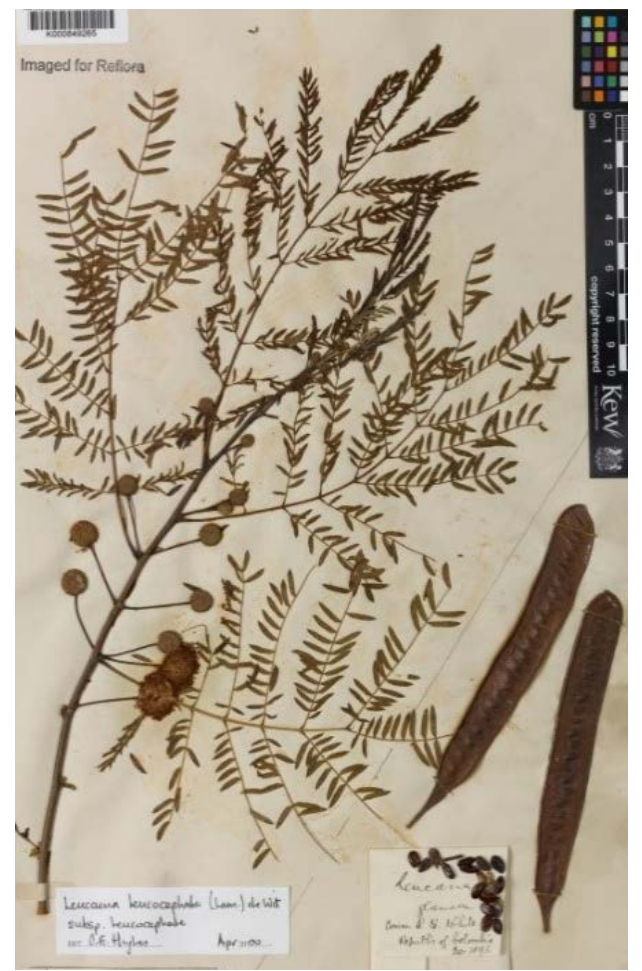

Image 7 - Exsicatae referring to 1872.

Source: Collection of Herbário Virtual Reflora, Royal Botanic Gardens, Kew, 2016 


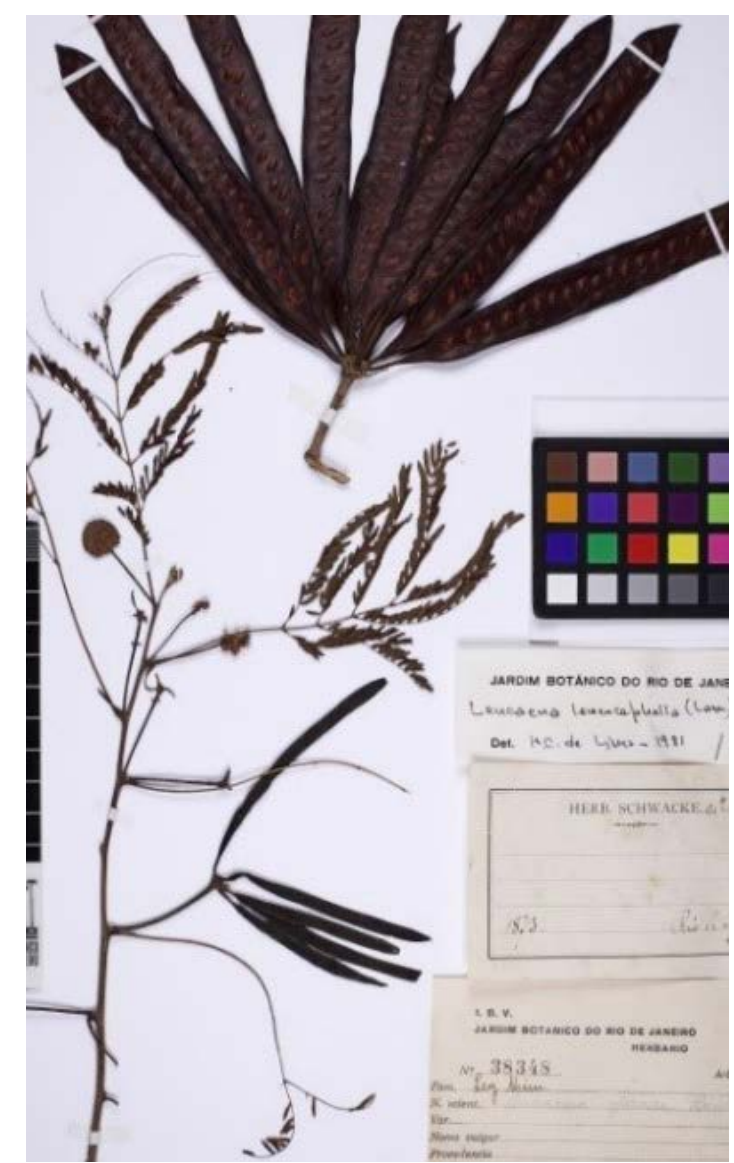

Image 8 - Exsicatae referring to 1873 .

Source: Collection of Herbário Virtual Reflora, Rio de Janeiro Botanical Garden, 2016.

Image 7 refers to the specimen collected in 1872 by Auguste François Marie Glaziou (1828-1906), a French civil engineer and landscape architect who lived in Brazil in 1858-1893. He collected plants in the states of Rio de Janeiro, São Paulo, Minas Gerais, Espírito Santo and Goiás (CASA DE RUI BARBOSA, 2017). The species was determined as Leucaena glauca Benth and was collected in the province of Rio de Janeiro. It was reclassified as Leucaena leucocephala (Lam.) de Wit. in 2000. Image 8 shows the sample collected in 1873 by Carl August Wilhelm Schwacke (1848-1904), a German botanist who spent several years in Brazil as a travelling naturalist for the Museu Nacional do Rio de Janeiro and as a professor of botany in the state of Minas Gerais (BIBLIOTECA VIRTUAL EM SAÚDE ADOLPHO LUTZ, 2017). The species was determined as Leucaena glauca Benth and was collected in Rio de Janeiro, being reclassified as Leucaena leucocephala (Lam.) de Wit. in 1981.

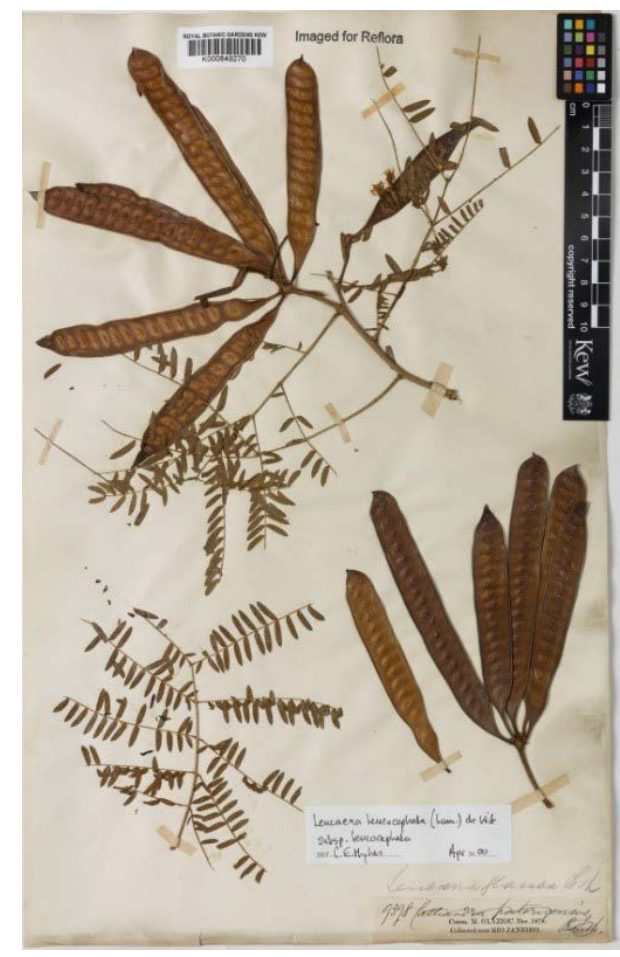

Image 9 - Exsicatae referring to 1878.

Source: Collection of Herbário Virtual Reflora, Royal Botanic Gardens, Kew, 2016.

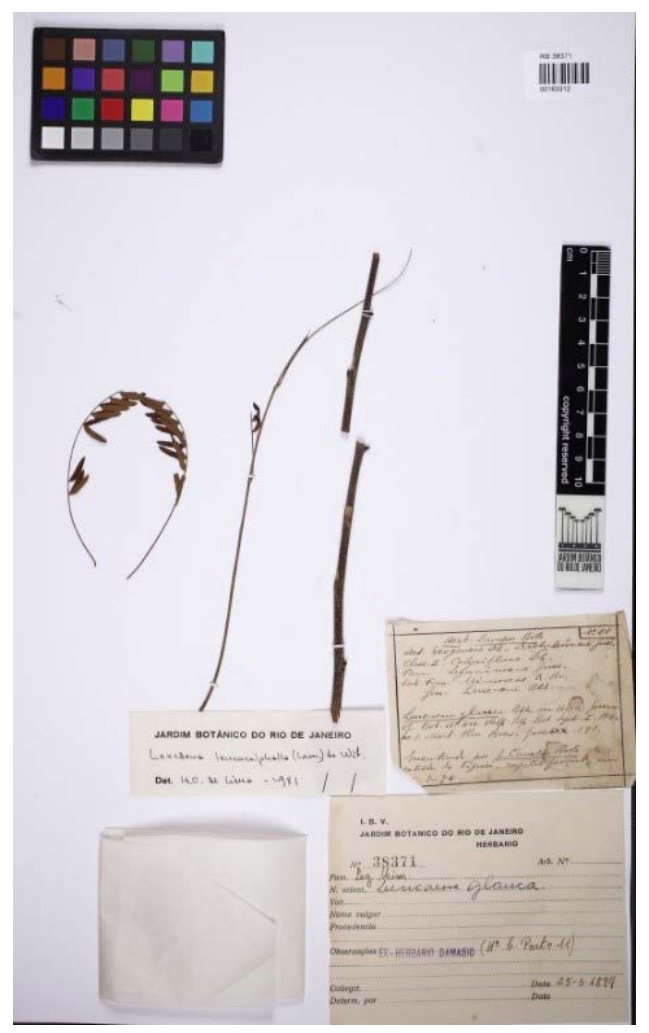

Image 10 - Exsicatae referring to 1894.

Source: Collection of Reflora Virtual Herbarium, Rio de Janeiro Botanical Garden, 2016. 
Image 9 depicts another sample collected by Auguste François Marie Glaziou. The species was determined as Leucaena glauca Benth and was collected in 1878, near the city Rio de Janeiro. The sample was reclassified as Leucaena leucocephala (Lam.) de Wit. in 2000. Image 10 represents a sample collected in 1894 by Joaquim Campos Porto (1839-1899). The species was determined as Leucaena glauca Benth and was collected near the city of Rio de Janeiro, on the Tijuca mountain range. In 1981 it was reclassified as Leucaena leucocephala (Lam.) de Wit.

The record found for the year 1898 refers to a sample collected by G. G. Huber Neto, in Belém, state of Pará. The species was determined as Leucaena leucocephala.

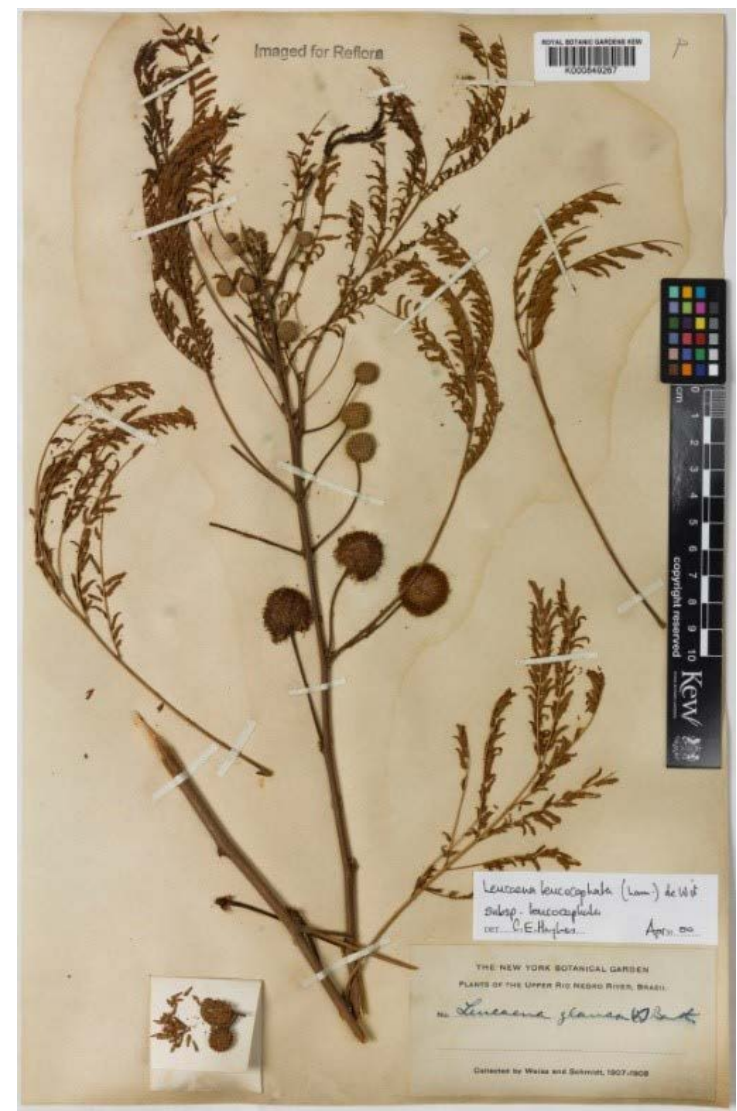

Image 11 - Exsicatae referring to 1907-1908.

Source: Collection of Reflora Virtual Herbarium, Royal Botanic Gardens, Kew, 2016.

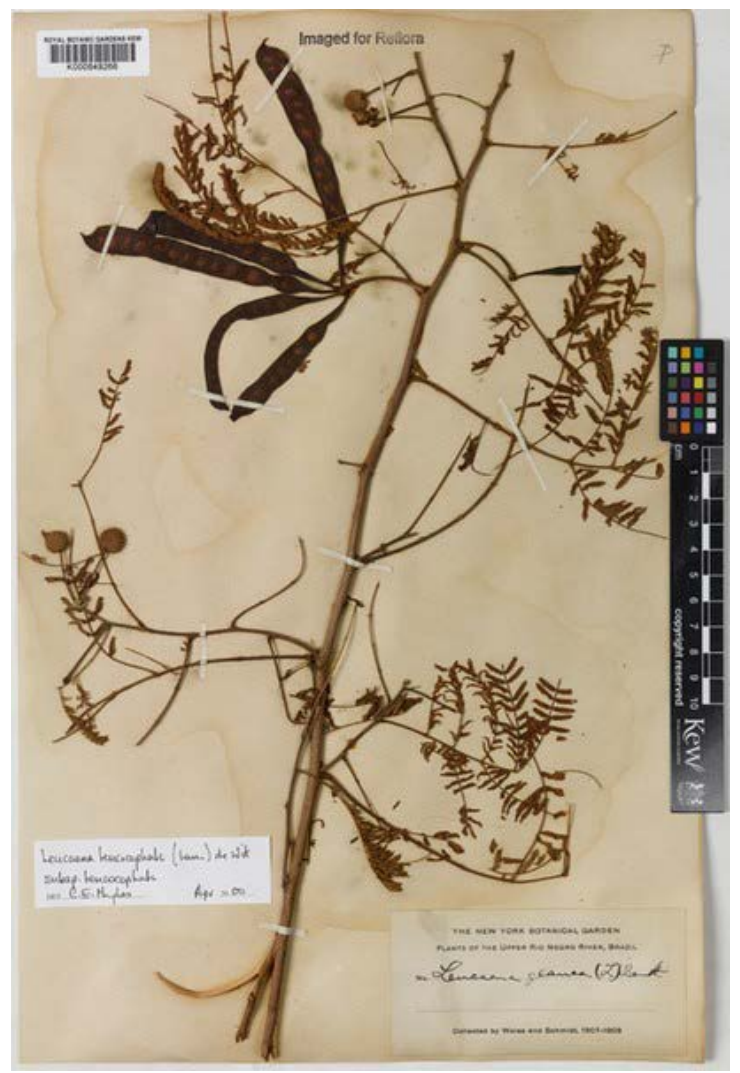

Image 12 - Exsicatae referring to 1907-1908.

Source: Collection of Reflora Virtual Herbarium, Royal Botanic Gardens, Kew, 2016.

The samples shown in Images 11 and 12 were collected in 1907/1908 by the German naturalist Hermann Schmidt and his collaborator Louis Weiss. The species was determined as Leucaena glauca Benth. It was collected in the upper Negro River, state of Amazonas. Samples were reevaluated in 1981 and reclassified as Leucaena leucocephala (Lam.) de Wit.

Image 13 shows a specimen collected in 1917 in Rio de Janeiro by the Brazilian botanist Frederico Carlos Hoehne (1882-1959), classified as Leucaena glauca Benth. The sample in Image 14 was collected in 1927 in Rio de Janeiro's Horto Florestal (a small urban forest reserve) by the Brazilian botanist João Geraldo Kuhlmann (1882-1958). The species was determined as Leucaena glauca Benth. 


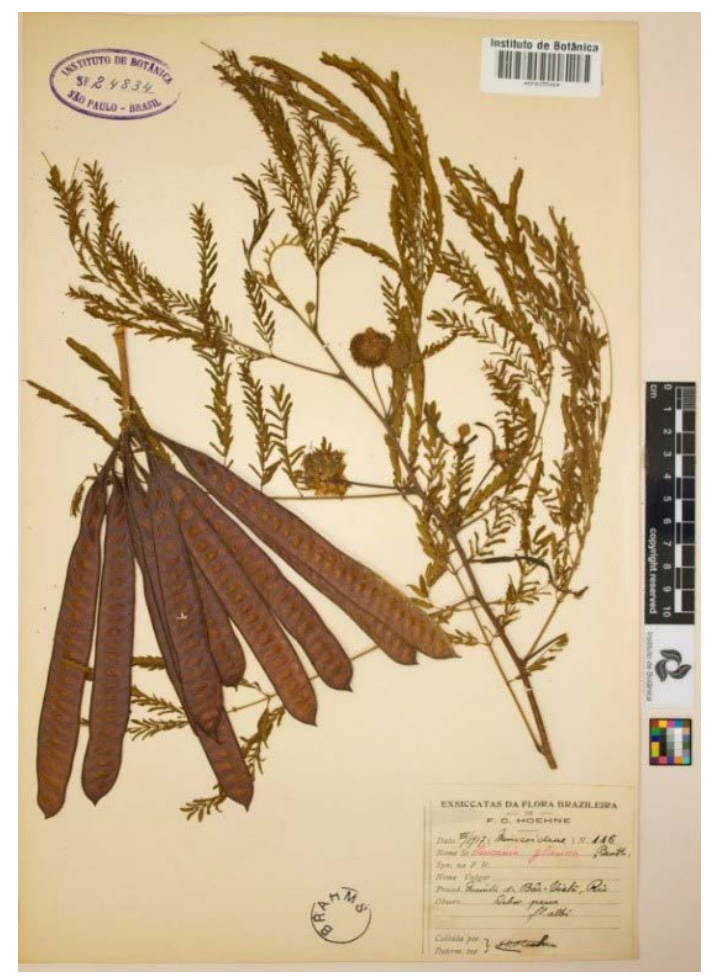

Image 13 - Exsicatae referring to 1917.

Source: Collection of Herbário SP, Instituto de Botânica, São Paulo, 2016.

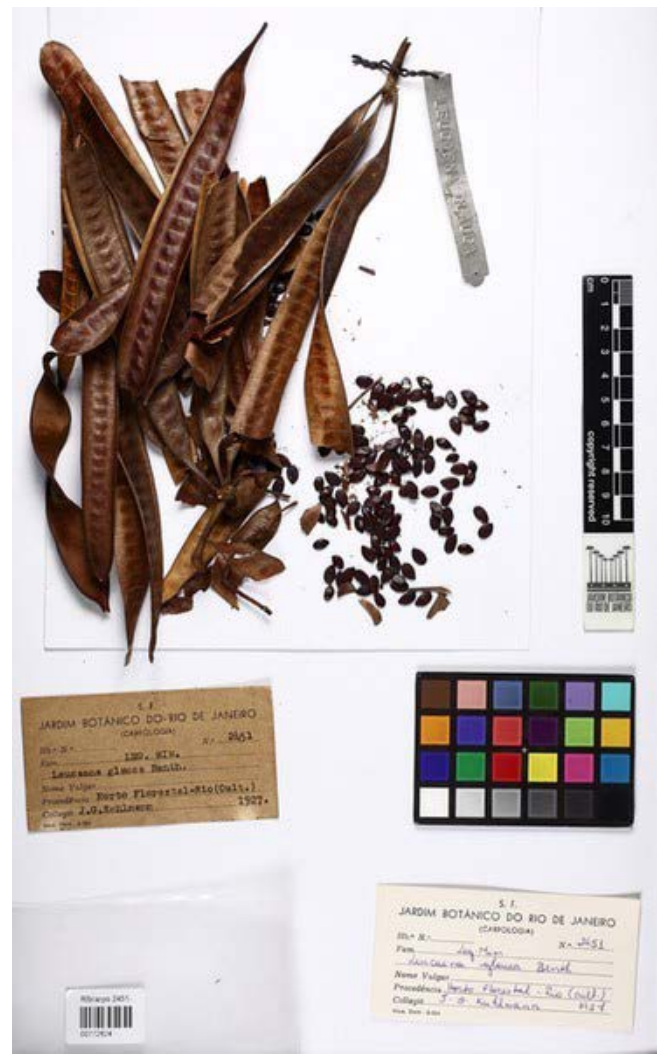

Image 14 - Exsicatae referring to 1927.

Source: Collection of Herbário Virtual Reflora, Rio de Janeiro Botanical Garden, 2016.
The record for the year 1918 represents a sample collected in the state of Bahia by H. M. Curran (18751960), a North American forester (JSTOR GLOBAL PLANTS, 2019). The species was determined as Leucaena leucocephala. The two records found for the year 1923 depict samples collected by Bento José Pickel (also known as Dom Bento Pickel, 19061963), a biologist and Benedictan monk (HARVARD UNIVERSITY HERBARIA \& LIBRARIES, 2017). The species of the two samples was determined as Leucaena leucocephala. The first one was collected in São Lourenço da Mata, state of Pernambuco. The second was collected in São Paulo, lacking a precise location.

The sample represented in Image 15 was collected in 1932 by J. Dutra in Osório, formlerly Conceição do Arroio, state of Rio Grande do Sul. The species was determined as Leucaena glauca Benth. Image 16 depicts the specimen collected in 1934 by Boris Alexander Krukoff (1898-1983), a Russian botanist and plantation manager who collected specimens in South and Central America, Caribbean, Africa, Southeast Asia and Australia (JSTOR GLOBAL PLANTS, 2019). This specimen was collected in the state of Amazonas, in the Madeira River basin. The sample was classified under the common name of faveira.

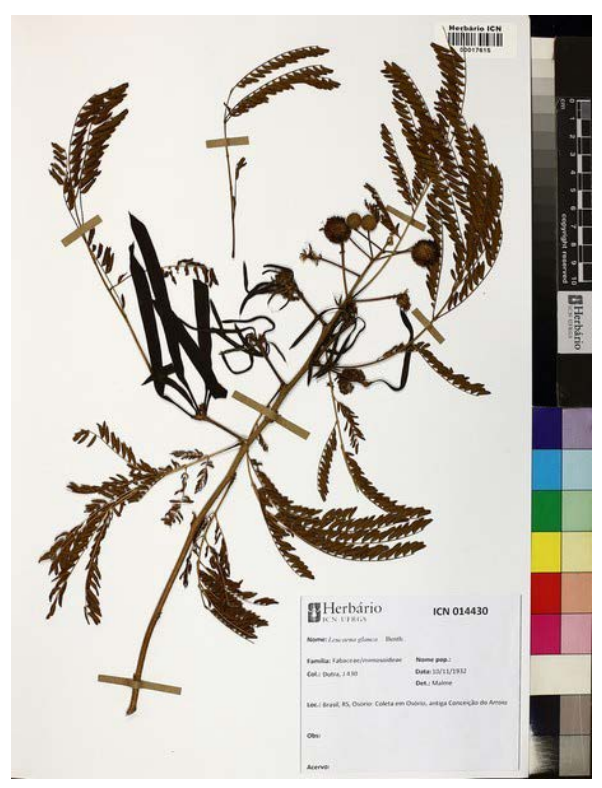

Image 15 - Exsicatae referring to 1932.

Collection: Collection of Herbário Virtual Reflora. Instituto de Ciências Naturais, Universidade Federal do Rio Grande do Sul, 2016. 


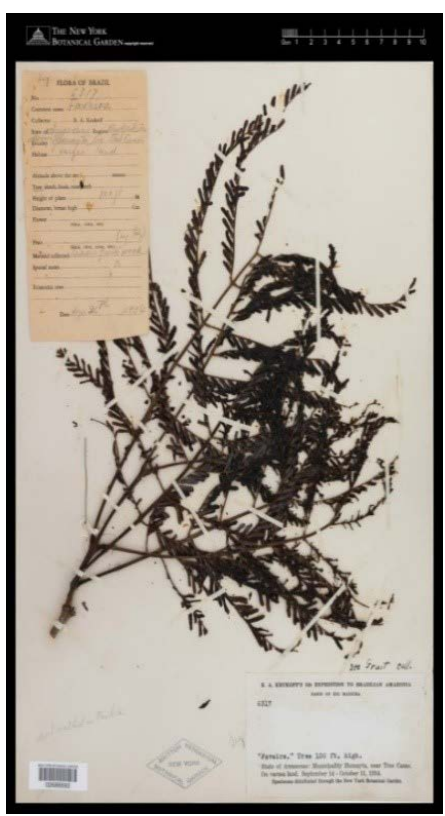

Image 16 - Exsicatae referring to 1934

Source: The C. V. Starr Virtual Herbarium - The New York Botanical Garden, 2016.

The record found for the year 1935 represents a sample collected by W. G. Houk at the Fazenda Santa Elisa, a farm in Campinas, state of São Paulo. The species was determined as Leucaena leucocephala in 2005.

Image 17 represents a sample collected in 1936 also by Bento José Pickel. The species was determined as Leucaena glauca Benth. It was collected in the state of Pernambuco, and reclassified as Leucaena leucocephala (Lam.) de Wit. in 1998.

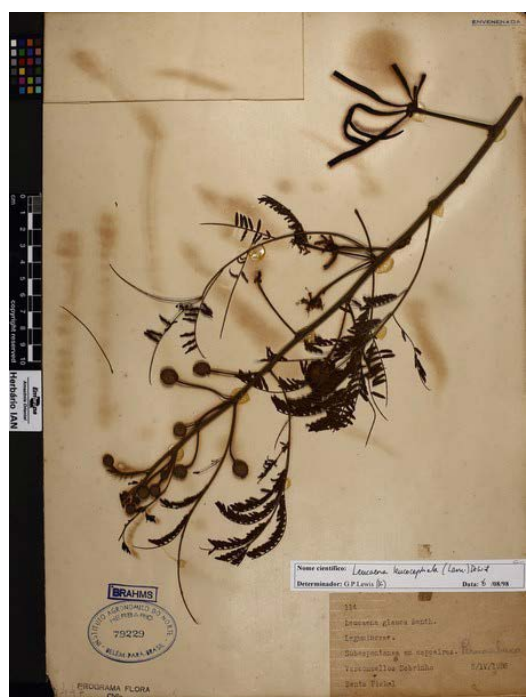

Image 17 - Exsicatae referring to 1936.

Source: Collection of Herbário Virtual Reflora, Herbário do Instituto Agronômico do Norte, 2016.

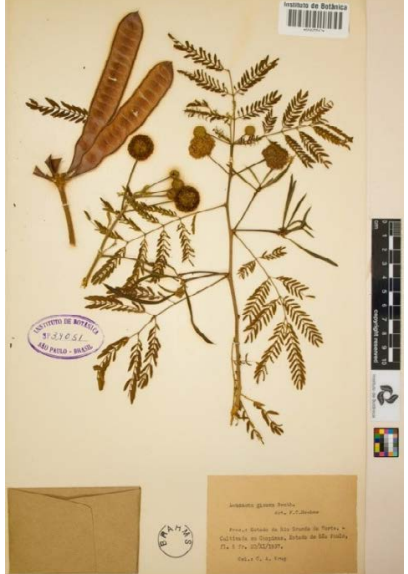

Image 18 - Exsicatae referring to 1937.

Source: Collection Herbário SP, Instituto de Botânica, São Paulo, 2016.

Another sample for the same year of 1936 was collected in São Lourenço da Mata, state of Pernambuco, by João Vasconcelos Sobrinho (1908-1989), a Brazilian soil scientist and conservation ecologist (GASPAR, 2008).

Image 18 depicts the sample collected in 1937 by the Brazilian soil scientist Carlos Arnaldo Krug (1906-1973) in the state of Rio Grande do Norte (CASA DE OSWALDO CRUZ/FIOCRUZ, 2017). The specimen was reported as having been "grown in Campinas" (probably cultivated), state of São Paulo. The sample was determined as Leucaena glauca Benth by Frederico Carlos Hoehne.

Image 19 shows the sample collected in 1938 by R. Alves Borges, in Alfenas, state of Minas Gerais. The species was determined as Leucaena leucocephala. by G. P. Lewis. The sample is described as a cultivated plant.

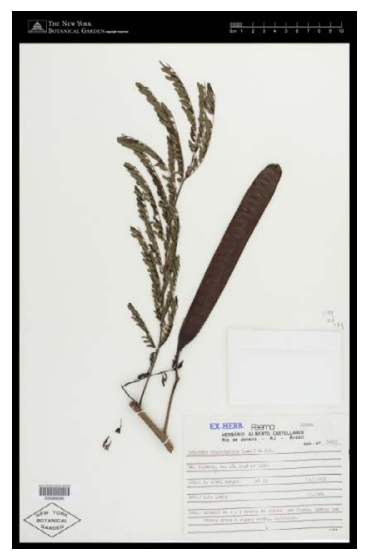

Image 19 - Exsicatae referring to 1938.

Source: The C. V. Starr Virtual Herbarium - The New York Botanical Garden, 2016. 


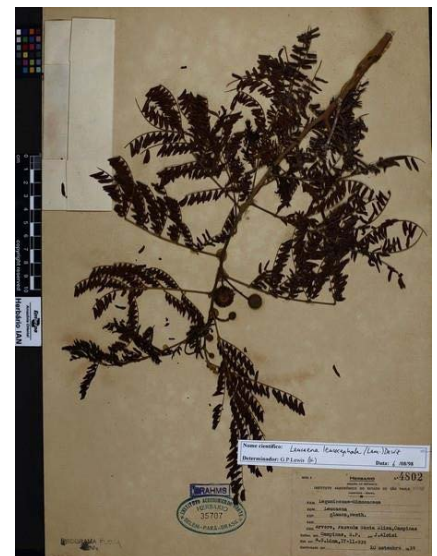

Image 20 - Exsicatae referring to 1939.

Source: Collection of Herbário Virtual Reflora, Herbário do Instituto Agronômico do Norte, 2016.

Another sample for the same year of 1938 was collected by the Brazilian soil scientist J. E. T. Mendes, at the Fazenda Santa Elisa, a farm in Campinas, state of São Paulo. The species was determined as Leucaena leucocephala by A. K. Pastorek in 2005.

Image 20 shows the sample collected in 1939 at the same Fazenda Santa Elisa, in Campinas, São
Paulo, by J. Aloisi. The species was determined as Leucaena glauca Benth. It was reclassified as Leucaena leucocephala (Lam.) de Wit. in 1998. Another sample for the same year of 1939 was collected by the Brazilian botanist Henrique Lahmeyer Mello Barreto (1892-1962) at an experimental farm near Belo Horizonte, state of Minas Gerais, probably cultivated. The species was determined as Leucaena leucocephala by Mamede, in 2008.

O. Kriegel, in Campinas, state of São Paulo, collected still another sample in 1939. The species was determined as Leucaena leucocephala.

\subsection{Records by year and date of collection}

Discarding duplicate records found in the three databases, we tallied a total of 536 individual records. They were plotted according to the years and decades in which respective collections occurred. Images 21 and 22 display the graphs illustrating these distributions.

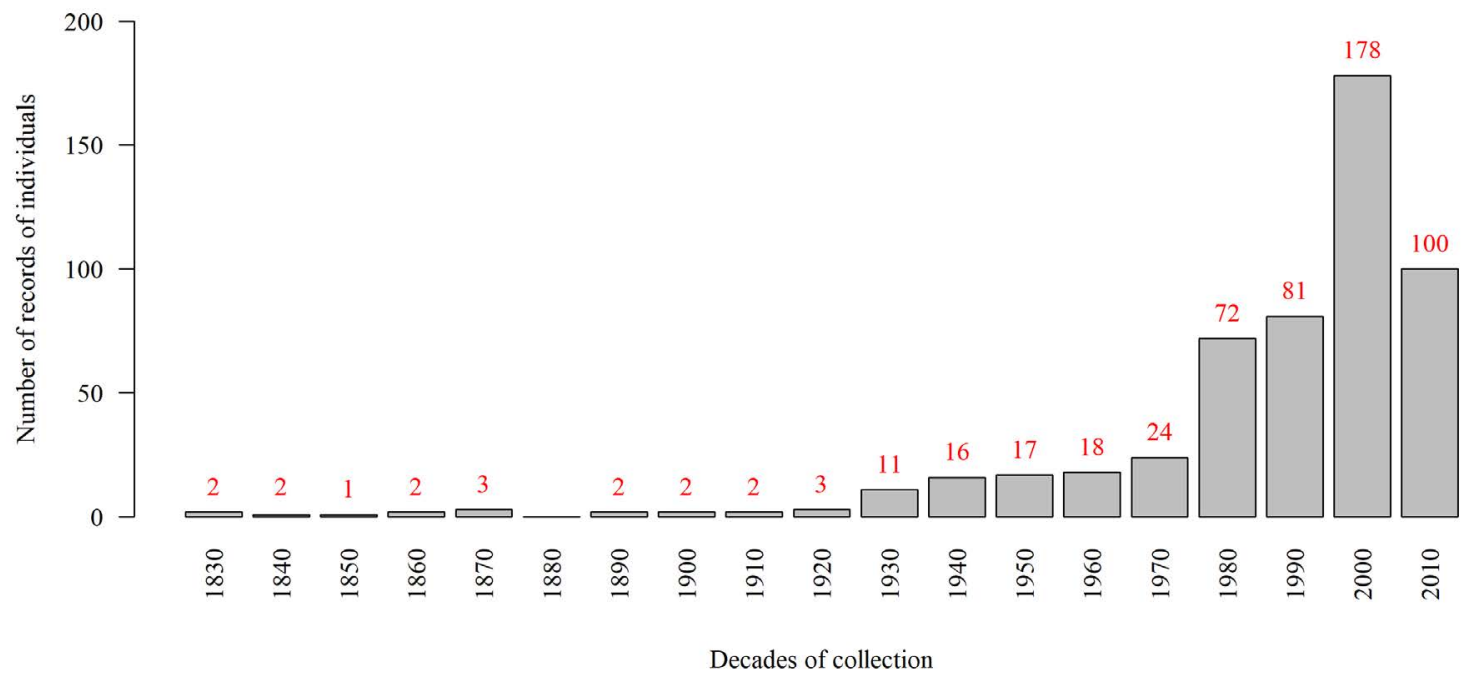

Image 21 - Numbers of records of Leucaena leucocephala in Brazil, per decade of collection, 1830-2010. Source: Authors' research.

As informed above, the first two records of collection occurred in Bahia in 1831 (1830s). In the following years and decades, the number of records remained low, reaching a maximum of three in the 1870 s and 1920s; no record was made in the 1880s. Between the 1930s and 1970s the number of records grew, reaching an average of almost 18 per decade. From the 1980 s to the
2010 s the number of records grew even more strongly; the highest number was 178 (2000s) and the average per decade jumped to 107.

\subsection{Distribution of the records of occurrence of the species in the Brazilian territory \\ Image 22 shows the spatial distribution of the records of Leucaena leucocephala in Brazilian}


territory. The species was collected in Brazil's five official geographic regions - North, Northeast, Center-South, Mid-West and South. The states of the North and Mid-West regions had low numbers of records. The area of the Atlantic Forest biome had the highest numbers of records. The Amazonia and
Pantanal biomes had less occurrences. Only two states, Amapá and Roraima, do not have records. The coastal states and / or located inside the original range of the Atlantic Forest had the highest numbers of records; this includes the states of São Paulo (97), Paraná (88), Bahia (71) and Pernambuco (65).

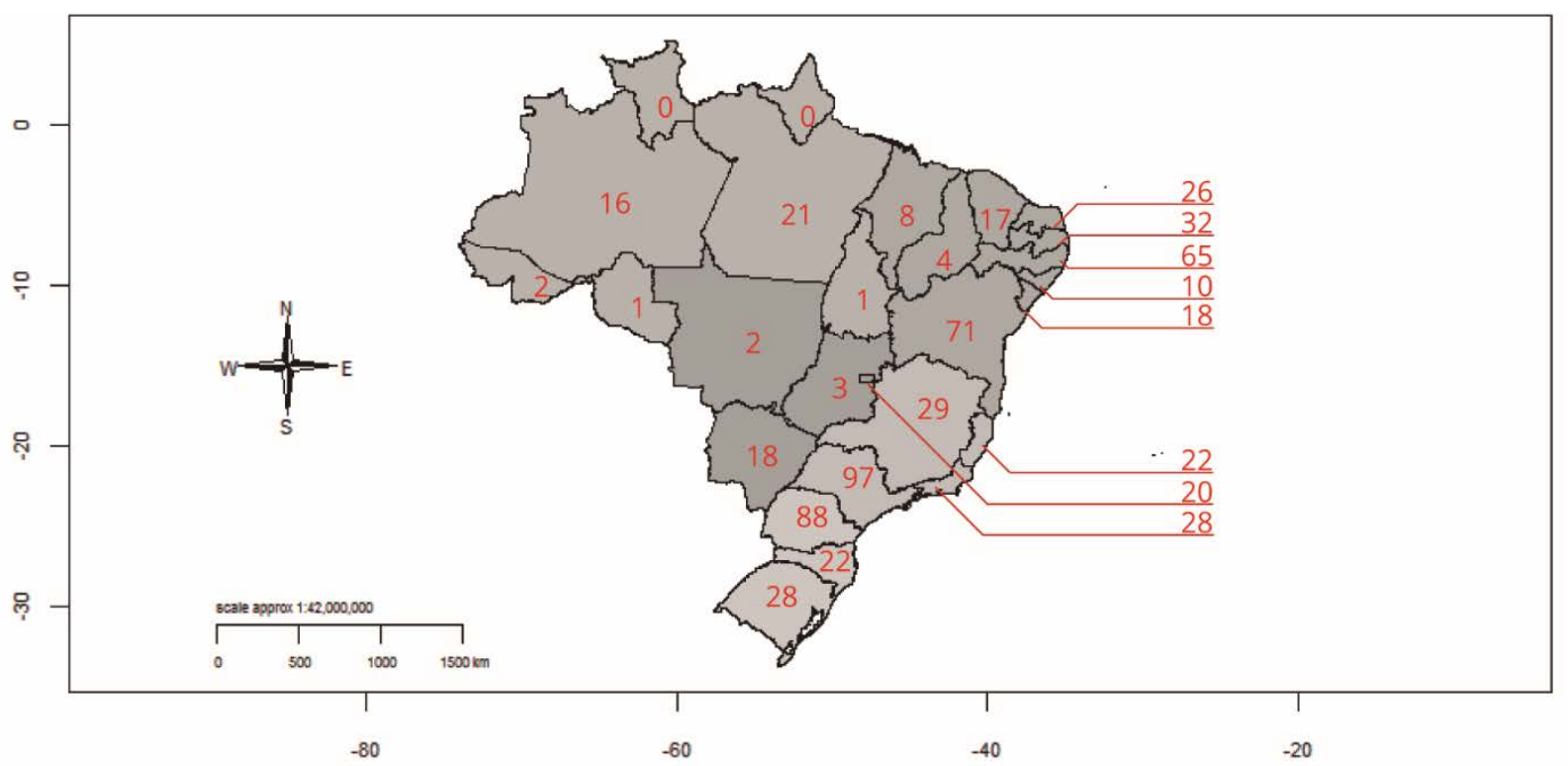

Image 22 - Brazil: numbers of recorded occurrences of Leucaena leucocephala, per state, 1831-2016. Source: Authors' research.

Image 23 shows, in addition to the number of each state. records per state, the date of the first record in

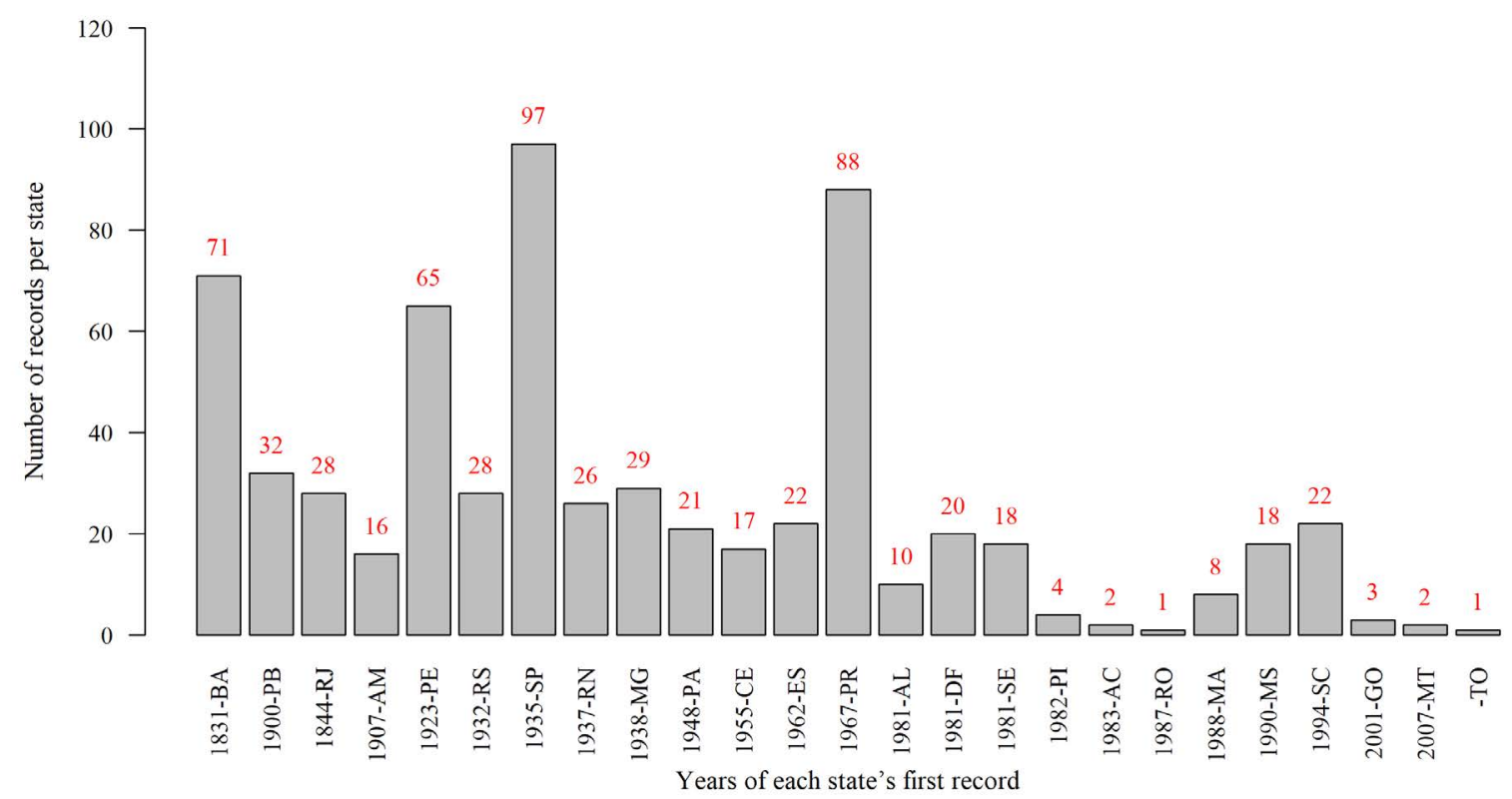

Image 23 - Brazil: numbers and dates of the first record of occurrence of Leucaena leucocephala, per state, 1831-2016.

Source: Authors' research. 
In addition to hosting the earliest recorded occurrence, Bahia reached 71 records, placing it among the Brazilian states with the highest number of records, surpassed only by Paraná (88) and São Paulo (97). Pernambuco also reached an expressive figure (65). The remaining states have much lower numbers - an average is 22 records. Piaui, Acre, Rondônia, Maranhão, Goiás, Mato Grosso and Tocantins were excluded from the computation of this average, since they had less than ten records each. Tocantins had only one record, undated.

\section{Discussion}

The three consulted databases are valuable sources of data on the occurrence of many plant species, invasive or not (ALBERNAZ; PIRES, 2009; PHILLIPS et al., 2004). In Brazil, most of the occurrences of the invasive Leucaena were recorded in the eastern or coastal swath of the territory, where most of the Brazilian population has lived and produced since colonial times. There are only sparser records for other areas of the country.

Collected data allow several more specific inferences. First, as stated aboove, the introduction of Leucaena in Brazil happened much earlier than 1940, the year that the literature has used for its original introducution. Leucaena was already present in Bahia in 1831 (VILELA; PEDREIRA, 1976). Herbarium records do not establish the actual dates of introduction, but they prove that Leucaena's arrival in Brazilian territory occurred long before its deliberate introduction by a research institution, in 1940 (HYNDMAN et al., 2015).

Second, there are records of more than 30 other occurences prior to 1940. This indicates that the records for 1831 are not anomalies.

Third, these early occurences (between 1831 and 1938) were recorded in eight states outside of São Paulo, where the first official occurrence was recorded, indicating that research efforts occurred in a fairly extensive part of the Brazilian territory. At the same time, the absence of data for certain regions may indicate a low priority given to species collection in other states (AIKIO et al., 2010).

Fourth, some of the more recent records (before 1940) inform or indicate that the plants were cultivated, or that they originated from cultivated stock. Although not definetly proven by herbaria data, this information suggests the possibility that the plant was, at least in some cases, deliberately introduced for the purpose of cultivation and use.

Fifth, a significant number of occurrences were recorded and/or classified by some of the socalled "travelling naturalists" of the early, middle and late $19^{\text {th }}$ century. This is just a small result of numerous efforts of non-Brazilian researchers and their supporting institutions to scour the tropical Brazilian territory in search of plant, animal and mineral specimens to be studied in museums, botanical gardens and universities located in Europe and the United States of America. Actually, some of the images displayed above show specimens that belong to these non-Brazilian institutions. This significant participation of foreign naturalists in the collection of Leucaena samples also expresses the scarcity of Brazilian scientists and scientific institutions during most of the $19^{\text {th }}$ century. The great importance of these scientists is expressed by Belluzzo (1999) and Kury (2012).

As mentioned above, Image 23 shows that the states located in the area originally occupied by the Atlantic Forest reached the highest number of records, with emphasis on São Paulo (97), Paraná (88), Bahia (71) and Pernambuco (65). This is not surprising in itself, as the list of Northeastern states displaying a significant presence of Leucaena leucocephala, compiled by Leão et al. (2011), includes only Pernambuco. Thus, our study fills a gap regarding the records of the species, because previous studies did not include important records of Leucaena leucocephala.

The data allowed us to illustrate (Image 22) the duration of the gaps between collection records. The reasons that led to these gaps may be many, but Nervo et al. (2010) emphasize that flawed sampling may taint collection campaigns. In addition, the possibilities of locating and collecting are subject to changes over time (AIKIO et al., 2010). Other factors are changing institutional support, availability of qualified personnel and shifting goals of collection campaigns. 
The scarcity of data on Leucaena in the early stages of its history in Brazil is visible in the first period of collection (1830 - 1920), which yields only 19 records in 90 years. The richer records of the second (1930 - 1970) and third (1980 - 2010) periods can be attributed to (i) the spreading of Leucaena and (ii) a growing attention given to the systematic research of the invasive potential of the species (HYNDMAN et al., 2015). There is also the possibility that the growing number of Brazilian trained biologists helped form a cadre of field scientists that reinforced research efforts during the last 50 years. In any case, it is difficult to dismiss the importance of these gaps, because low numbers of records do not mean that the species had not yet started its process of establishment and expansion (COUSENS; MORTIMER, 1995).

Results also allow the identification of at least a few specific places where Leucaena was introduced. This can help define the environmental conditions that aid the establishment of the species (COLAUTTI; MACISAAC, 2004). Additionally, results allow us to build timelines of potential invasions (COUSENS et al., 2013). These time lines are useful to determine the species' circulation flow (FUENTES et al., 2008) and to estimate propagation rates in different environments (PYŠEK; HULME, 2005) over time. This of course may inform strategies designed to reduce the species' chances of establishment (MacDOUGALL et al., 1998; KRICSFALUSY; TREVISAN, 2014) and contain its dissemination. This can be done by investigating the species' population status at each recorded site and identifying human activities that may have contributed to its dissemination (KRICSFALUSY; TREVISAN, 2014).

In conclusion, Leucaena, as a species endowed with strong invasive traits, has had much more time to spread, either on its own or with thelp of humans, in numerous places unrelated to its official point of introduction, in Campinas, state of São Paulo. The combination of Leucaena being a domesticated plant with other factors mentioned above may help explain its rather extensive distribution in the Brazilian territory.

\section{Acknowledgements}

Funding: This work was supported by University of Brasilia through the CAPES/PROAP - 2015 program [reference \# 02/2016] and by CNPQ (Brazil's national research council). The authors also thank the New York Botanical Garden and the "Maria Eneyda P. Kaufman Fidalgo" Herbarium (State of São Paulo, Brazil) for allowing the use of exsicatae images. Other images do not require specific authorization.

\section{Participation of each author in the study}

The three authors identified in the submission process participated fully in the research design, in its execution and in the drafting of the submitted manuscript. The first author found and organized the virtual herbaria data - texts and exsicatae images - on the studied species. All three authors gathered information about the collectors and classifiers and about the historical context of their activities. The three authors also participated in the search and use of the relevant analytical and conceptual literature, in the drafting of the text (including results and discussion). Maps and graphs were conceived by the first author. The second author, a native speaker of English, was responsible for finishing the submitted text.

\section{References}

AIKIO, Sami; DUNCAN, Richard P.; HULME, Philip E. Lag-phases in alien plant invasions: separating the facts from the artifacts. Oikos, Copenhagen, $v$. 119, n. 2, p. 370-378, 2010. https://doi.org/10.1111/j. 1600-0706.2009.17963.x

ALBERNAZ, Ana Luisa Kerti Mangabeira; ÁVILA-PIRES, Teresa Cristina Sauer (org.). Espécies ameaçadas de extinção e áreas críticas para biodiversidade no Pará. Belém: Museu Paraense Emílio Goeldi, 2009. https://doi.org/10.1590/s198181222009000200004

BELLUZZO, Ana Maria de Moraes (ed.). O Brasil dos viajantes. São Paulo: Metalivros, 1999.

BIBLIOTECA VIRTUAL EM SAÚDE ADOLPHO LUTZ. [Site]. 2019. Disponivel em: http://www.bvsalutz.coc. fiocruz.br/. Acesso em: 01 mar. 2017.

BLOSSEY, Bernd; NÖTZOLD, Rolf. Evolution and increased competitive ability in invasive nonindigenous plants: a hypothesis. Journal of Ecology, Oxford, v. 83, n. 5, p. 887-889, 1995. https://doi. org/10.2307/2261425 
GARDNER, G.; PINHEIRO, A. Viagens pelo Brasil principalmente nas províncias do norte e nos distritos do ouro e do diamante durante os anos de 1836-1841. São Paulo: Companhia Editora Nacional, 1942. (Biblioteca Pedagógica Brasileira, série n. 5, Brasiliana, v. 223).

BREWBAKER, James L. Guide to the systematics of genus Leucaena (Mimosaceae). Cali: Centro Internacional de Agricultura Tropical, 1978.

BREWBAKER, James L.; SORENSSON, Charles T. Domestication of lesser-known species of Leucaena In: LEAKEY, R.; NEWTON, A. (eds.). Tropical trees: the potential for domestication. Edinburgh: Institute of Terrestrial Ecology, 1994. p. 195-204

BURDICK, Alan. Out of eden. New York: Farrar, Strauss and Giroux, 2005.

CASA DE OSWALDO CRUZ. Dicionário histórico-biográfico das ciências da saúde no Brasil 1832-1930. Rio de Janeiro: Fiocruz, [2018]. Disponivel em: http:// www.dichistoriasaude.coc.fiocruz.br. Acesso em: 13 mar. 2017. https://doi.org/10.33167/2184-0644. cpp2017.viiin1/pp.147-160

CASA DE RUI BARBOSA. Glaziou: o paisagista do Império. Rio de Janeiro: Fundação Casa de Rui Barbosa, [2010]. Disponivel em: http://www.casaruibarbosa.gov. br/glaziou/biografia.htm. Acesso em: 13 mar. 2017. https://doi.org/10.18764/2178-2865.v22n1p363-370

CASAS, Alejandro; CABALLERO, Javier. Traditional management and morphological variation in Leucaena esculenta (Fabaceae: Mimoisoideae) in the Mixtec region of Guerrero, Mexico. Economic Botany, New York, v. 50, p. 167-181, 1996. https://doi.org/10.1007/bfo2861449

CENTRO AGRONOMICO TROPICAL DE INVESTIGACION Y ENSEÑANZA. Leucaena, Leucaena leucocephala (Lam. de Wit.): espécie de árbol de use múltiple em América Central. Turrialba: [s. n.], 1991. https:// doi.org/10.11606/d.11.2019.tde-20191108-103128

COSTA, José Nicola Martorano Neves; DURIGAN, Giselda. Leucaena leucocephala (Lam.) de Wit (Fabaceae): invasora ou ruderal? Revista Árvore, Viçosa, v. 34, n. 5, p. 825-833, 2010. https://doi.org/10.1590/ s0100-67622010000500008

COSTA, Newton L. et al. Avaliação agronômica de genótipos de Leucena em Ariquemes, Rondônia. Porto Vetho: EMBRAPA-Rondônia, 2004. Comunicado Técnico.

COLAUTTI, Robert I.; MACISAAC, Hugh. J. A neutral terminology to define 'invasive' species. Diversity and Distribution, New Jersey, v. 10, p. 135-141, 2004 https://doi.org/10.1111/j.1366-9516.2004.00061.x

COUSENS, Roger D. et al. Reassessment of the invasion history of two species of Cakile (Brassicaceae) in Australia. Cunninghamia, Sydney, v. 13, p. 275-290, 2013. https://doi.org/10.7751/cunninghamia.2013.005

COUSENS, Roger D.; Mortimer, Martim. Dynamics of weed populations. Cambridge: Cambridge University, 1995.

CROSBY, Alfred W. The Columbian exchange. Westport: Greenwood, 1973.
CROSBY, Alfred W. Ecological imperialism. Cambridge: Cambridge University, 1986.

DEAN, Warren. Brazil and the Struggle for Rubber. Cambridge: Cambridge University, 1987.

DIJKMAN, Marinus J. Leucaena: a promising soil erosion control plant. Economic Botany, New York, v. 4, n. 4, p. 337-349, 1950. https://doi.org/10.1007/ bf02985092

ELTON, Charles S. The ecology of invasions by animals and plants. Chicago: Chicago University, 2000

EVANS, Lloyd. T. The domestication of crop plants. In: EVANS, Lloyd. T. (ed.). Crop evolution, adaptation and yield. Cambridge: Cambridge University, 1993. p. 62-112.

FUENTES, Nicol et al. Alien plants in Chile: inferring invasion periods from herbarium records. Biological Invasions, Amsterdam, v. 10, n. 5, p. 649-657, 2008. https://doi.org/10.1007/s10530-007-9159-0

GASPAR, Lúcia. Vasconcelos Sobrinho. Recife: Fundação Joaquim Nabuco, 2008. Disponivel em: http:// basilio.fundaj.gov.br/pesquisaescolar/index.php?option=com content\&view $=$ article\&id=126\&ltemid=1. Acesso em: 28 mar. 2019.

GLOBAL BIODIVERSITY INFORMATION FACILITY. [Site]. Copenhagen: GBIF, [2019]. Disponivel em: https://www.gbif.org/. Acesso em: 01 nov. 2016.

Global Invasive Species Database. [Site]. [S. l.]: GISD, 2019. Disponivel em: http://www.iucngisd.org/gisd/ search.php. Acesso em: 26 ago. 2019.

HARVARD UNIVERSITY HERBARIA \& LIBRARIES. Index of botanists. Cambridge: Harvard University, [2017]. Disponivel em: http://kiki.huh.harvard.edu/ databases/botanist_search.php?id=10982. Acesso em: 20 mar. 2017.

HUGHES, Colin E. Leucaena genetic resources: the OFI seed collections and a synopsis of species characteristics. Oxford: Oxford Forestry Institute, 1993.

HUGHES, Colin E. Leucaena: manual de recursos genéticos. Oxford: Oxford Forestry Institute, 1998.

HYNDMAN, Rob J.; MESGARAN, Mohsen B.; COUSENS, Roger D. Statistical issues with using herbarium data for the estimation of invasion lag-phases. Biological Invasions, Amsterdam, v. 17, n. 12, p. 3371-3381, 2015. https://doi.org/10.1007/s10530-015-0962-8

BEDIAGA, Begonha; DRUMMOND, Renata Pizarro Cronologia: Jardim Botânico do Rio de Janeiro. Rio de Janeiro: Jardim Botânico do Rio de Janeiro, 2007. Disponivel em: https://www.jbrj.gov.br/sites/all/ themes/corporateclean/content/publicacoes/ cronologia.pdf. Acesso em: 13 mar. 2017. https://doi. org/10.17771/pucrio.acad.4140

JOHNSON, Sarah (ed.). Bioinvaders. Cambridge: The White Horse, 2010

JSTOR GLOBAL PLANTS. [Site]. [S. l.]: JSTOR, [2019]. Disponivel em: https://plants.jstor.org/search?filter=name\&so=ps_group_by_genus_species+asc\& Query=blanchet. Acesso em: 15 mar. 2017. 
JSTOR GLOBAL PLANTS. Curran, Hugh McCullum (1875-1960). [S. l.]: JSTOR, [2019]. Disponivel em: https://plants.jstor.org/stable/10.5555/al.ap.person. bmo00001758. Acesso em: 29 mar. 2019.

JSTOR GLOBAL PLANTS. Krukoff, Boris Alexander (1898-1983). [S. l.]: JSTOR, [2019]. Disponivel em: https://plants.jstor.org/stable/10.5555/al.ap.person. bmo00004612. Acesso em: 29 mar. 2019.

KLUTHCOUSKI, João. Leucena: alternativa para a pequena e média agricultura. Brasília: EMBRAPA-CNPAF, 1992. (Circular Técnica, n. 6)

KRICSFALUSY, Vladimir V.; TREVISAN, Nicholas. Prioritizing regionally rare plant species for conservation using herbarium data. Biodiversity and Conservation, Amsterdam, v. 23, n. 1, p. 39-61, 2014. https://doi. org/10.1007/s10531-013-0583-4

KURY, Lorelai Brilhante (ed.). Sertões adentro: viagens nas caatingas, séculos XVI a XIX. Rio de Janeiro: Andrea Jakobsson Estudio, 2012.

LEÃO, Tarciso C. C. et al. Espécies exóticas invasoras no nordeste do Brasil: contextualização, manejo e políticas públicas. Recife: CEPAN, 2011.

LEOPOLD, Aldo. A sand county almanac, and sketches here and there. New York: Ballantine, 1987.

LIMA, Paulo César F. Leucena. In: KIILL, Lúcia Helena P.; MENEZES, Eduardo A. (ed.), Espécies vegetais exóticas com potencialidades para o semi-árido. Petrolina: Embrapa Semi-Árido, 2005. p. 157-205.

LOW, Tim. Feral future. Chicago: University of Chicago, 2001.

LOWE, Sarah et al. 100 of the world's worst invasive Alien Species: a selection from the global invasive species database. Auckland: The Invasive Species Specialist Group, 2000. https://doi. org/10.1163/9789004278110_019

MACDOUGALL, Andrew S. et al. Defining conservation priorities for plant taxa in southern New Brunswick, Canada, using herbarium records. Biological Conservation, Essex, v. 86, p. 325-338, 1998. https://doi.org/10.1016/s0006-3207(98)00031-7

MATTOS, Antônio Jorge Santos Silva. Uso de alimentos alternativos na criação da paca (Cuniculus paca). 2015 Dissertação (Mestrado em Ciência Animal) - Programa de Pós-Graduação em Ciência Animal, Departamento de Ciências Agrárias e Ambientais, Universidade Estadual de Santa Cruz, Ilhéus, 2015. https://doi. org/10.18605/2175-7275/cereus.vgn3p66-80

MCCANN, James C. Maize and Grace: Africa's encounter with a New World Crop. Cambridge: Harvard University, 2007.

MORETTO, Samira Peruchi. História ambiental e as migrações do reino vegetal: a domesticação e a introdução de plantas. In: GERHARDT, Marcos; NODARI, Eunice Sueli; MORETTO, Samira Peruchi (ed.). História ambiental e migrações: diálogos. São Leopoldo: Oikos, 2017. https://doi. org/10.7476/9788564905689.0008
NATIONAL ACADEMY OF SCIENCE. Leucaena: promising forage and tree crop for the tropics. Washington: National Academy, 1977.

NERVO, Michele H.; WINDISCH, Paulo G.; LORSCHEITTER, Maria Luisa. Representatividade da base amostral da pteridoflora do estado do Rio Grande do Sul (Brasil) e novos registros de distribuição. Pesquisas Botânica, São Leopoldo, n. 61, p. 245-258, 2010. https://doi.org/10.11606/d.6.2016.tde-22012016-143325

NOBLE, lan R. Attributes of invaders and the invading process: terrestrial and vascular plants. In: DRAKE, James A. et al. (ed.). Biological invasions: a global perspective. New York: Willey, 1989. p. 301-313.

PYŠEK, Petr; HULME, Philip E. Spatio-temporal dynamics of plant invasions: linking patterns to process. Écoscience, Quebec, v. 12, n. 3, p. 302-315, 2005. https://doi.org/10.2980/i1195-6860-12-3-302.1

Reader, John. Potato: a story of the propitious esculent. New Haven: Yale University, 2008.

Reflora: Herbário Virtual. Virtual herbarium. [S. L.]: Reflora, [2016]. Disponivel em: http://www.herbariovirtualreflora.jbrj.gov.br/reflora/herbarioVirtual/. Acesso em: 19 mar. 2017.

REJMÁNEK, Marcel. Species richness and resistance to invasions. In: ORIANS, Gordon; DIRZO, Rodolfo; CUSHMAN, J. Hall (ed.). Biodiversity and ecosystem processes in tropical forests. New York: Springer, 1996. p. 153-172. https://doi.org/10.1007/978-3-642-79755-2_8

ROYAL BOTANICAL GARDEN, KEW. William John Burchell. [S. l.]: Kew, [2019]. Disponivel em: http:// apps.kew.org/herbcat/gotoBurchell.do. Acesso em: 29 mar. 2019.

SCHIFINO-WITTMANN, Maria Teresa. Leucena: do México para o mundo, a globalização das árvores de mil e uma utilidades. In: BARBIERI, Rosa Lía; STUMPF, Elisabeth Regina T. (ed.). Origem e evolução de plantas cultivadas. Brasilia: Embrapa, 2008. p. 437-463.

SIMBERLOFF, Daniel. Invasive species. New York: Oxford University, 2013

SPECIESLINK. [Site]. [S. l.: s. n., 2019]. Disponivel em: http://splink.cria.org.br. Acesso em: 01 nov. 2016.

SOUSA, Francisco B. Leucena: alternativa forrageira de alta qualidade para caprinos e ovinos. Sobral: EMBRAPA Caprinos e Ovinos, 2001. https://doi. org/10.31692/2526-7701.iicointerpdvagro.2017.00552

NEW YORK BOTHANICAL GARDEN. C. V. Starr Virtual Herbarium. New York: New York Botanical Garden, [2016]. Disponivel em: http://sweetgum.nybg.org/ science/vh/ Acesso em: 11 nov. 2019. https://doi. org/10.5860/choice.51-6176

TODD, Kim. Tinkering with Eden. New York: Norton, 2001.

VILELA, Edmilson; PEDREIRA, José Vicente S. Efeito de densidades de semeadura e niveis de adubação nitrogenada no estabelecimento de Leucaena leucocephala (Lam) de Wit. Boletim de Indústria Animal, Nova Odessa, v. 33, n. 2, p. 251-280, 1976. 
WALTON, Craig S. Leucaena (Leucaena leucocephala) in Queensland: pest status review. Brisbane: Department of Natural Resources and Minas, 2003. (Series Land Protection).

WORSTER, Donald. Transformations of the earth: toward an agroecological perspective in history. The Journal of American History, [s. L.], v. 76, n. 4, p. 10871106, 1990. https://doi.org/10.2307/2936586

ZÁRATE PEDROCHE, Sergio. Revisión del genero Leucaena in Mexico. Serie Botanica. Anales del Instituto de Biologia, Mexico, v. 65, n. 2, p. 83-162, 1994.

\section{Marilia Teresinha de Sousa Machado}

Doutora em Desenvolvimento Sustentável pela Universidade de Brasília (UnB), Brasilia, Brasil. Pesquisadora Colaboradora do Centro de Desenvolvimento Sustentável da Universidade de Brasília (CDS-UnB), Brasilia, Distrito Federal, Brasil.

\section{José Augusto Drummond}

Doutor em Recursos da Terra (Universidade de Wisconsin, Madison, USA). Professor associado IV no Centro de Desenvolvimento Sustemtável (CDS- UnB).

\section{Cristiane Gomes Barreto}

Doutora em Desenvolvimento Sustentável, Universidade de Brasilia (UnB); Docente no Centro de Desenvolvimento Sustentável (UnB); Brasília, DF. Brasil;

\section{Mail address}

Marilia Teresinha de Sousa Machado.

QE 36 conjunto G casa 21, Guará II. Brasilia, DF. 71065073. Brazil.

\section{José Augusto Drummond}

SQN 206, Bloco J, Apt 10. Asa Norte. Brasília - DF, Brasil. 70844-100.

\section{Cristiane Gomes Barreto}

Campus Universitário Darcy Ribeiro, Asa Norte, Brasília - DF, 70.910-900. 